\title{
Most Recent Heart Failure Event
}

National Cancer Institute

\section{Source}

National Cancer Institute. Most Recent Heart Failure Event. NCI Thesaurus. Code C67103.

The most recent occurrence of heart failure. 